\title{
Performance evaluation of modified BAU self-propelled reaper for paddy
}

\section{Md. Mahamudun Noby, Md. Kamrul Hasan, Md. Rostom Ali, Chayan Kumer Saha, Md. Monjurul Alam and Md. Mosharraf Hossain}

Department of Farm Power and Machinery, Bangladesh Agricultural University, Mymensingh-2202, Bangladesh

\begin{tabular}{|c|c|}
\hline ARTICLE INFO & Abstract \\
\hline $\begin{array}{l}\text { Article history: } \\
\text { Received: 06 February } 2018 \\
\text { Accepted: } 29 \text { July } 2018\end{array}$ & \multirow{3}{*}{$\begin{array}{l}\text { Bangladesh has an agrarian economy in which paddy is the dominant crop. Significant amount of field } \\
\text { losses of paddy occurs every year due to natural calamities and shortage of time during harvesting period. } \\
\text { During this study, a modification was done on locally developed BAU self-propelled reaper and its } \\
\text { performance was compared with manual harvesting system of paddy. Several experiments were conducted } \\
\text { in Boro paddy (April-May } 2017 \text { ) and Aman paddy harvesting (November-December } 2017 \text { ) at BAU farm } \\
\text { of Bangladesh Agricultural University after necessary modification works in the workshop. An } \\
\text { experiment was also conducted on Aman paddy in } 2017 \text { at BAU farm for determining manual harvesting } \\
\text { cost. The technical and economic performances of the modified BAU self-propelled reaper were } \\
\text { determined based on the field experiments. Results reveal that average fuel consumption, effective field } \\
\text { capacity and field efficiency were } 2.71 \mathrm{~L} / \mathrm{ha}, 0.255 \mathrm{ha} / \mathrm{h} \text { and } 77.27 \% \text {, respectively for the modified BAU } \\
\text { self-propelled reaper, and } 2.88 \mathrm{~L} / \mathrm{ha}, 0.25 \mathrm{ha} / \mathrm{h} \text { and } 75.76 \% \text {, respectively for the existing BAU self- } \\
\text { propelled reaper. These results indicated that field performances of modified BAU self-propelled reaper } \\
\text { were better than that of the existing BAU reaper. Paddy harvesting cost was found } 916 \mathrm{Tk} / \mathrm{ha} \text { for modified } \\
\text { BAU self-propelled reaper and } 9200 \mathrm{Tk} / \mathrm{ha} \text { for manual harvesting system. Benefit cost ratio of the } \\
\text { modified BAU self-propelled reaper was } 2.18 \text {. Considering the technical and economic performances, } \\
\text { modified BAU self-propelled reaper was found suitable than the existing BAU reaper. So, the modified } \\
\text { BAU self-propelled reaper may be introduced in Bangladesh in commercial basis. }\end{array}$} \\
\hline $\begin{array}{l}\text { Keywords: } \\
\text { Paddy, Harvesting, Reaper, Field } \\
\text { loss, Cost saving }\end{array}$ & \\
\hline $\begin{array}{l}\text { Correspondence: } \\
\text { Md. Rostom Ali } \\
\text { (rustom412@yahoo.com) }\end{array}$ & \\
\hline
\end{tabular}

\section{Introduction}

Bangladesh is basically an agricultural country. World Bank (2016) reported that more than 70 percent of Bangladesh's population and 77 percent of its workforce lives in rural areas. Nearly half of all of Bangladesh's workers and two-thirds in rural areas are directly employed by agriculture, and about 87 percent of rural households rely on agriculture for at least part of their income. Paddy is a major cereal crop in agriculture that contributes to national food security and socio-economic development. In 2015-16 fiscal year, agriculture contributed $17 \%$ of GDP (BBS, 2016). Harvesting of paddy is traditionally done by sickle by both male and female farmers in Bangladesh (Pandey and Devnani, 1985). Traditional manual harvesting of paddy using a sickle is a quite tedious and labor intensive job. Due to migration of labor in nonagricultural sectors, shortage of labor and cost for paddy harvesting are serious problems in peak harvesting season. Zhang et al. (2014) mentioned about a progressive shrinking of rural labor availability, as workers migrate to cities or abroad to engage in more remunerative employment, particularly in the garments and construction sectors. Timely harvesting operation of paddy is a crucial and important process for quantity, quality and production cost of paddy. Significant amount of field losses of paddy occurs in every year due to natural calamities, shortage of time during harvesting period and delayed harvesting. Samon and Duff (1973) reported that 5, 7 and 10 days delayed harvest resulted in 3,6 and $11 \%$ decrease in paddy yield, respectively. Iqbal et al. (1980) developed mathematical models for the harvesting and threshing losses of wheat in the field. They found that manual harvesting losses increase linearly with time, ranging from $3 \%$ in the first week to $7 \%$ in the third week after ripening of the crop.

Mechanization of agricultural activities is to increase the labor productivity, cropping intensity and cost reduction. Hossain et al. (2015) showed that average time, cost and grain that could be saved by using combine harvester over manual methods are $97.50 \%, 35.00 \%$ and $2.75 \%$, respectively. Mechanization also helps in better management of farm by proceeding more free time for planting of next crop. Meisner et al. (1997) showed that a reaper is 14 times more efficient than a daily laborer in cutting and placing cereals in the field. Appropriate farm mechanization has been emphasized as an important policy and development goal in Bangladesh (Mandal, 2002, 2014; Zhang et al., 2014). So, suitable machinery, especially harvesting machinery, is a crying need to increase production with less drudgery.

Mechanical harvesting of paddy by using a reaper minimizes the time, drudgery, labor involvement, harvesting losses and increases the cropping intensity. In Bangladesh, all the imported reapers are operated by petrol engine. Generally, retail price of petrol is $90 \mathrm{Tk} / \mathrm{L}$ and that of diesel is $65 \mathrm{Tk} / \mathrm{L}$. For reducing operating cost, a reaper, called BAU self-propelled reaper, was developed (Hossain, 2003) through REFPI project during 1997-2003. The reaper was run by diesel fuel- 
operated $5 \mathrm{hp}$ engine (Model: Z175F-1). In today's world, where fuel price is increasing as a consequence of spiraling demand and diminishing supply, it is necessary to choose a cost-effective fuel to meet the needs. Diesel is available in all places, but petrol is not available in all local markets. The diesel engine has proved to be extremely efficient and cost effective. Accessories of diesel engine are also available in the local market and the cost of diesel engine accessories is much cheaper than petrol engine.

Field performance of the existing BAU reaper was not satisfactory due to several mechanical problems like straw clogging during the operation because of lower cutter bar speed than forward speed and slipping problem of cage wheel. In addition to these, there were also observed some minor problems like weight unbalanced, turning problem due to the clutch adjustment, excessive vibration, excessive noise, and improper adjustment of star wheel and spring. Therefore, the main objectives of the study were to assess the present status of the existing BAU self-propelled reaper through field operations and to modify the reaper and test its field performance.

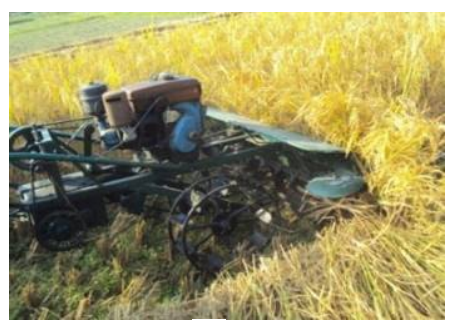

a

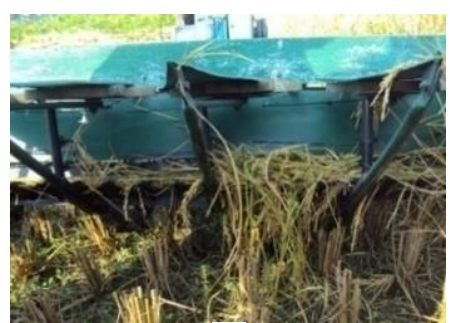

b

\section{Materials and Methods}

\section{Study location}

The modification works of BAU self-propelled reaper were done in the Engineering workshop under the Department of Farm Power and Machinery of Bangladesh Agricultural University and the field experiments were conducted at the BAU farm, Mymensingh, Bangladesh.

\section{Problems associated with existing BAU self-propelled reaper}

In Aman/2016, the existing BAU self-propelled reaper was tested to harvest paddy at BAU farm after long time (about 10 years) idle conditions of the reaper. During idle period, the reaper was not used due to several functional problems like (i) weight unbalanced, (ii) straw clogging with cutter bar and chain, (iii) improper adjustment of belt and pulley, (iv) slipping problem due to cage wheels, (v) poor condition of the prime mover (diesel engine), (vi) improper adjustment of vertical power transmission shaft with dog sprocket, (vii) improper adjustment of star wheel and spring and (viii) lower cutter bar speed than that of forward speed. Some identified problems during Aman/2016 paddy harvesting are shown in Fig. 1.

Fig. 1. Photographic views of Aman/2016 harvesting: a) using existing BAU self-propelled reaper b) straw clogged with cutter bar and chain, c) iron cage wheel of reaper

\section{Modification of BAU self-propelled reaper}

Identified problems were minimized in the engineering workshop under the Department of Farm Power and Machinery, Bangladesh Agricultural University. Iron cage wheels were changed by tyre wheel for better traction and less slipping to reduce forward speed and avoid straw clogging. For increasing cutter bar speed, 4 inch cutter bar pulley was replaced by 4.5 inch diameter pulley. An additional support like an idler pulley was incorporated with belt power transmission system, which increased belt tension for proper power transmission. Star wheels and springs were adjusted after dismantling those parts for proper rotation and transferring of straw during harvesting. Vertical power transmission shaft was welded and adjusted with dog sprocket. Several sections of the reaper were dismantled and adjusted for balancing the weight of the reaper. Some modification activities before Boro/2017 paddy harvesting are shown in Fig. 2.

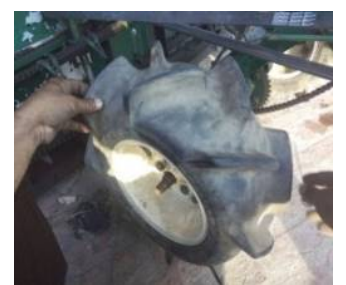

a

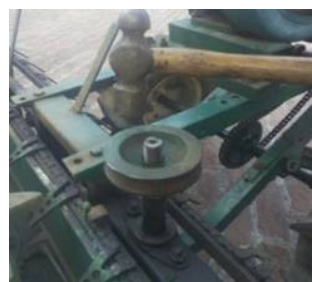

b

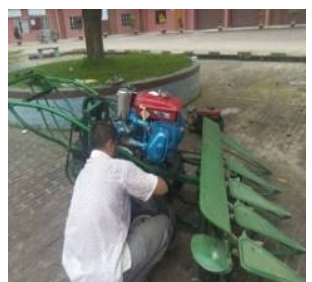

C

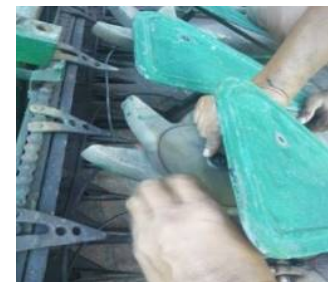

d

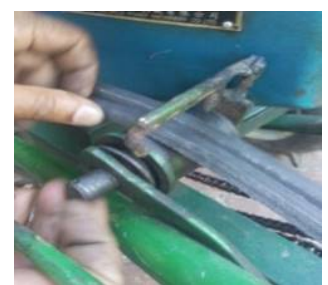

e

Fig. 2. a) Iron cage wheel replaced by tyre wheel, b) cutter bar pulley changed, c) old engine was replaced by new one, d) star wheel adjustment in engineering workshop, and e) belt and pulley setting adjustment 
Selection of pulley

At first, paddy was harvested using BAU self-propelled reaper with $114.3 \mathrm{~mm}\left(4.5^{\prime \prime}\right)$ pulley, but the ratio of cutting and forward speed of reaper was found 1.01. It was decided to increase the cutter bar speed of the reaper. As there were no facilities for changing the cutting speed through gear box mechanism, the cutting speed was changed by varying the pulley size at second transmission shaft. For that three pulleys were purchased from local market. The sizes of the pulleys were 114.3 $\left(4.5^{\prime \prime}\right), 127\left(5^{\prime \prime}\right)$ and $139.7\left(5.5^{\prime \prime}\right) \mathrm{mm}$. Internal bore and slot were made for each pulley in the workshop to fit them with the transmission shaft. Three pulleys of different sizes are shown in Fig. 3.

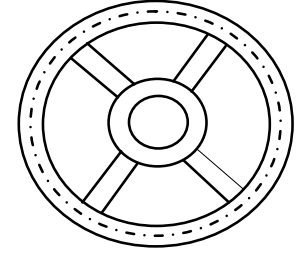

Dia 139.7 mm (5.5")

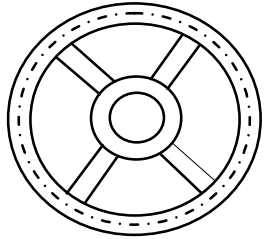

Dia 127 mm (5.0")

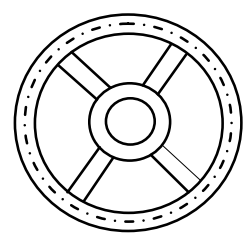

Dia $114.3 \mathrm{~mm}\left(4.5^{\prime \prime}\right)$

Fig. 3. Front views of three different sizes pulleys $(139.7,127 \& 114.3 \mathrm{~mm})$

\section{Harvesting operations}

In Bangladesh, mainly two types of harvesting operation are in practice: manual harvesting and mechanical harvesting systems. So, two methods of paddy harvesting were used at the experimental sites during Aman/2016, Boro/2017 and Aman/2017 paddy harvesting seasons. These were: a) traditional method (manually using sickle) and b) modern/mechanical method (using existing and modified BAU selfpropelled reaper).

\section{Manual harvesting cost and loss}

For determination of manual harvesting cost and losses, 3 (three) plots were selected and all plots were harvested by manually using sickle as shown in Fig. 4. For cost calculation, required harvesting time and labor were counted and finally calculated based on the appropriate mathematical equations. For comparison of harvesting loss between manual and mechanical systems, two types of losses were measured, i.e. i) shatter and ii) cutter bar losses. Matured drop paddy from the panicle caused by bird, wind, rats, and handling operations were collected and measured. After completing the harvesting operation, uncut plant stems were also collected carefully and kept on the polythene sheet for estimating cutting loss as shown in Fig. 5.

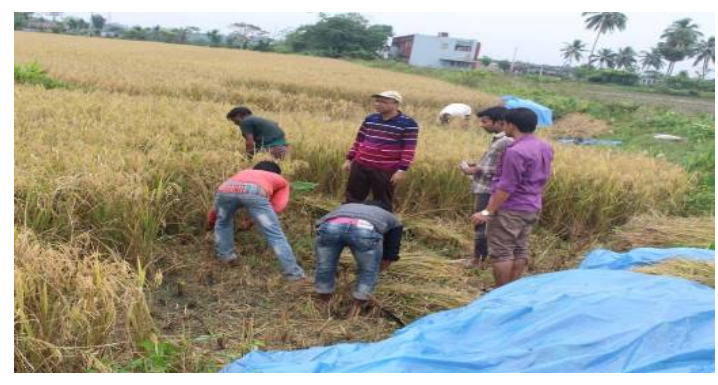

Fig. 4. Manual harvesting by sickle at BAU Farm

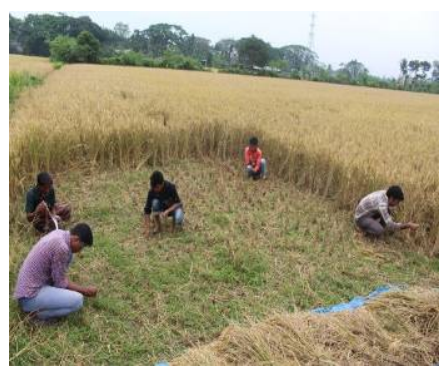

Fig. 5. Collection of dropped paddy and uncut stem

\section{Paddy harvesting using modified BAU self-propelled reaper}

Field performance of the BAU self-propelled reaper was tested at BAU farm during Aman/2016, Boro/2017 and Aman/2017 seasons after necessary modifications of the reaper.

Performance evaluating indicators of BAU selfFor the technical and economic performances analysis of mechanical harvesting of paddy, the indicators considered were: (i) operational time, (ii) working speed, (iii) field capacity, (iv) cutting efficiency, (v) labor requirement for harvesting, (vi) grain yield, (vii) grain losses, and (viii) fuel consumption.
Field capacity and field efficiency

Field capacity and field efficiency were determined (Hunt, 1995) as follows:

Effective field capacity $(\mathrm{ha} / \mathrm{h}), \mathrm{C}_{\mathrm{eff}}=\frac{A}{T}$

where $\mathrm{C}_{\text {eff }}=$ effective field capacity $(\mathrm{ha} / \mathrm{h})$

$\mathrm{T}=$ total time for the reaping operation (including lost time), $\mathrm{h}$

$\mathrm{A}=$ area coverage, ha

Theoretical field capacity $(\mathrm{ha} / \mathrm{h}), \mathrm{C}_{\mathrm{th}}=\frac{w S}{10}$

where $\mathrm{C}_{\mathrm{th}}=$ theoretical field capacity $(\mathrm{ha} / \mathrm{h})$

$\mathrm{S}=$ rated forward speed of machine $(\mathrm{km} / \mathrm{h})$

$\mathrm{W}=$ rated width of the cutter bar $(\mathrm{m})$ 
Field efficiency (\%), e $=\frac{C_{\text {eff }}}{C_{\text {th }}} \times 100$

Cutting efficiency

Cutting efficiency was determined (Hunt, 1995) as

Cutting efficiency $(\%)=\frac{e-d}{e} \times 100$

where $\mathrm{e}=$ number of plant per square meter before reaping and $d=$ number of uncut plant per square meter.

\section{Cost calculation for mechanical harvesting}

Cost analysis for BAU self-propelled reaper for the harvesting of paddy, especially cost of operation of the machine, was determined by considering fixed cost and variable cost. Harvesting cost and time of mechanical harvesting system were also compared with manual harvesting system.

\section{Fixed costs}

The fixed cost is the cost, which is involved irrespective of whether the machine is used or not. This cost includes i) depreciation cost, ii) interest on investment, and iii) taxes, shelter and insurance.

\section{i) Depreciation cost}

Depreciation is the reduction in value of a machine with the passes of time. Depreciation cost was calculated by straight line method (Hunt, 1995) as follows:

The annual depreciation, $D=\frac{P-S}{L}(\mathrm{Tk} / \mathrm{yr})$

where $P=$ purchase price, Tk, $S=$ selling price, Tk. and $L=$ time between buying and selling, yr.

\section{ii) Interest on investment}

Interest on the investment in a farm machine is a legitimate cost, since money spent in buying a machine cannot be used for other productive enterprises, it was calculated by Straight Line Method (Hunt, 1995) as

Interest on investment, $I=\frac{P+S}{2} i$

where $P=$ Purchase price, $\mathrm{Tk}, S=$ Re-sale value, $\mathrm{Tk}$, and $i=$ annual interest rate.

Cost saving for using reaper $(\mathrm{Tk} / \mathrm{ha})=$ Cost for manual method $(\mathrm{Tk} / \mathrm{ha})-$ cost for harvesting through reaper $(\mathrm{Tk} / \mathrm{ha})$ Cost saving $(\%)=\underline{\text { Cost for manual harvesting }(\mathrm{Tk} / \mathrm{ha})-\text { Cost for mechanical harvesting }(\mathrm{Tk} / \mathrm{ha})} \times 100$

$$
\text { Cost for manual harvesting }(\mathrm{Tk} / \mathrm{ha})
$$

\section{Results and Discussion}

Performance of BAU self-propelled reaper

After using existing BAU self-propelled reaper and modified BAU self-propelled reaper, the measured average forward speed, fuel consumption, effective field capacity, theoretical field capacity and field efficiency are presented in Table 1. According to the results mentioned in Table 1, field performances of modified BAU self-propelled reaper was found better than that of existing BAU self-propelled reaper. Improved performance was obtained due to mechanical iii) Taxes, shelter and insurance

In the experiment, shelter, tax and insurance, $S T I=2.5 \%$ of $P$ was considered for calculating fixed cost of harvesting machine (Hunt, 1995).

\section{Total fixed cost}

Total fixed cost was estimated (Hunt, 1995) as

Total fixed cost $(\mathrm{Tk} / \mathrm{yr})=D+I+S T I$.

Fixed $\operatorname{cost}(\mathrm{Tk} / \mathrm{ha})=\frac{\text { Total Fixed Cost }(\mathrm{Tk} / \mathrm{Yr})}{\text { Total Area Coverage }(\mathrm{ha} / \mathrm{Yr})}$

\section{Variable costs}

Fuel cost, oil cost, labor cost and repair \& maintenance cost were determined (Barger et al., 1987) as

Oil cost, $O(\mathrm{Tk} / \mathrm{ha})=15 \%$ of fuel cost, $F$.

Fuelcost, $\mathrm{F}(\mathrm{Tk} / \mathrm{ha})=\frac{\text { Fuelconsumed }(\mathrm{L} / \text { day }) \times \text { Price }(\mathrm{Tk} / \mathrm{L})}{\text { Areacovered }(\text { ha } / \text { day })}$..

Loborcost, $\mathrm{L}(\mathrm{Tk} / \mathrm{ha})=\frac{\text { Sumof wagesof labor }(\mathrm{Tk} / \text { day })}{\text { Areacovered(ha/day) }}$

Repair and maintenance cost, $\mathrm{R} \& \mathrm{M}(\mathrm{Tk} / \mathrm{ha})=0.025 \%$ of purchase price, $P$.

Total variable cost was determined using Eq.12 and total harvesting cost was determined using Eq.13.

Total variable cost $=(\mathrm{F}+\mathrm{O}+\mathrm{L}+\mathrm{R} \& \mathrm{M}) \mathrm{Tk} / \mathrm{ha}$......(12)

Total cost of harvesting $(\mathrm{Tk} / \mathrm{ha})=$ Fixed cost $(\mathrm{Tk} / \mathrm{ha})+$ Variable cost (Tk/ha)

\section{Cost calculation for manual harvesting}

Manual harvesting cost depends on labor rate and number of labor required for the area to be harvested. It was determined using Eq.14.

Total cost $(\mathrm{Tk} / \mathrm{ha})=$ Wage of laborer $(\mathrm{Tk} / \mathrm{man}) \times$ No. of laborer (man/ha)

\section{Cost saving by mechanical harvesting}

The costs of two different paddy harvesting methods like reaper and manual harvesting systems were compared to determine the benefits of mechanical harvesting system over manual harvesting. modification of belt, pulley, star wheel adjustment, balance adjustment. Replacement of new wheel and diesel engine with the modified reaper was also supported to obtain improve performance.

\section{Field capacity and field efficiency}

After modification works, field capacity and field efficiency were determined for the different pulley sizes as provided in Table 2 . There is no significant difference in field capacity and field efficiency for different pulley sizes but comparative better performances were found for the pulley size 5.5 inches. 
Table 1. Field performance of BAU self-propelled reaper

\begin{tabular}{ccccccc}
\hline Harvesting machine & $\begin{array}{c}\text { Obs. } \\
\text { No. }\end{array}$ & $\begin{array}{c}\text { Forward } \\
\text { speed, } \\
\mathrm{km} / \mathrm{h}\end{array}$ & $\begin{array}{c}\text { Fuel } \\
\text { consumption, } \\
\text { L/ha }\end{array}$ & $\begin{array}{c}\text { Effective field } \\
\text { capacity, } \\
\text { (ha/h) }\end{array}$ & $\begin{array}{c}\text { Theoretical } \\
\text { field capacity, } \\
\text { ha/h }\end{array}$ & $\begin{array}{c}\text { Field } \\
\text { efficiency, } \\
\%\end{array}$ \\
\hline & 1 & 2.73 & 2.87 & 0.2480 & 0.3276 & 75.70 \\
Modified BAU self- & 2 & 2.78 & 2.69 & 0.2578 & 0.3336 & 77.28 \\
propelled reaper & 3 & 2.79 & 2.56 & 0.2618 & 0.3348 & 78.20 \\
$\begin{array}{c}\text { Existing BAU self- } \\
\text { propelled reaper }\end{array}$ & Avg. & 2.77 & 2.71 & 0.2550 & 0.3320 & 77.06 \\
\begin{tabular}{c} 
(Hossain, 2003) \\
\hline
\end{tabular} & & 2.75 & 2.88 & 0.25 & 0.33 & 75.76 \\
\hline
\end{tabular}

Table 2. Comparison of field performances on the basis of using different sizes pulley

\begin{tabular}{|c|c|c|c|c|c|c|c|}
\hline \multirow{2}{*}{$\begin{array}{l}\text { Pulley } \\
\text { size } \\
\text { (inch) }\end{array}$} & \multicolumn{3}{|c|}{ Effective field capacity, $\mathrm{C}_{\text {eff }}(\mathrm{ha} / \mathrm{h})$} & \multicolumn{3}{|c|}{$\begin{array}{l}\text { Theoretical field capacity, } \\
\qquad \mathrm{C}_{\text {th }}(\mathrm{ha} / \mathrm{h})\end{array}$} & \multirow{2}{*}{$\begin{array}{c}\text { Field } \\
\text { efficiency, }(\%)\end{array}$} \\
\hline & $\begin{array}{c}\text { Area } \\
\text { reaped, A } \\
\left(\mathrm{m}^{2}\right)\end{array}$ & $\begin{array}{l}\text { Time, T } \\
\text { (min) }\end{array}$ & $\begin{array}{c}\text { Effective field } \\
\text { capacity, A/T } \\
(\text { ha } / \mathrm{h})\end{array}$ & $\begin{array}{l}\text { Forward } \\
\text { speed, } \\
\mathrm{S}(\mathrm{km} / \mathrm{h})\end{array}$ & $\begin{array}{c}\text { Effective } \\
\text { width, w (m) }\end{array}$ & $\begin{array}{c}\text { Theoretical field } \\
\text { capacity, wS/10 } \\
(\mathrm{ha} / \mathrm{h})\end{array}$ & \\
\hline 4.5 & 1418.32 & 34.31 & 0.2480 & 2.73 & 1.2 & 0.3276 & 75.70 \\
\hline 5.0 & 730.45 & 17.00 & 0.2578 & 2.78 & 1.2 & 0.3336 & 77.28 \\
\hline 5.5 & 752.85 & 17.25 & 0.2618 & 2.79 & 1.2 & 0.3348 & 78.20 \\
\hline
\end{tabular}

Effect of cutting and forward speeds on throwing performance

A comparative analysis for cutting and forward speeds of modified BAU self-propelled reaper during paddy harvesting is given in Table 3 .

Straw cutting performance of the reaper during harvesting operation was not affected using different cutting speeds as mentioned in Table 3. Throwing performance was affected by the ratio of cutting and forward speeds. Throwing performance increases gradually with increasing the ratio of cutting and forward speeds. Cutting performance was measured by counting the uncut stem and the roughness of cutting parts, on the other hand throwing performance was measured by observing the throwing and dropping of cutting straw or stem in line at the field without hazard. The throwing performance was found more satisfactory for the ratio of cutting and forward speeds 1.21.

\section{Effect of pulley size on cutting efficiency}

Cutting efficiency increased with increased pulley sizes (4.5", 5.0", 5.5" dia.) (Table 4). A pulley having larger diameter makes more cutting speed with throwing performance as shown in Fig. 6. In the field, higher cutting and throwing speeds help to reduce the cutting losses. The rates of uncut straw reduced with increase of pulley size of BAU self-propelled reaper.

Table 3. Average forward speed, cutting speed and ratio of cutting and forward speed

\begin{tabular}{|c|c|c|c|c|c|c|c|}
\hline $\begin{array}{l}\text { Pulley size } \\
\text { (inch) }\end{array}$ & $\begin{array}{l}\text { Obs. } \\
\text { No. }\end{array}$ & $\begin{array}{c}\text { Distance } \\
\text { travelled }(\mathrm{m})\end{array}$ & $\begin{array}{l}\text { Time } \\
(\mathrm{min})\end{array}$ & $\begin{array}{l}\text { Forward } \\
\text { speed, } V_{\mathrm{f}} \\
(\mathrm{m} / \mathrm{min})\end{array}$ & $\begin{array}{l}\text { Avg. forward } \\
\text { speed, } V_{f} \\
(\mathrm{~m} / \mathrm{min})\end{array}$ & $\begin{array}{c}\text { Cutting Speed, } \\
\mathrm{V}_{\mathrm{c}}=\frac{2 L n_{11}}{1000}(\mathrm{~m} / \mathrm{min})\end{array}$ & Ratio, $\mathrm{R}_{\mathrm{c}}=\mathrm{V}_{\mathrm{c}} / \mathrm{V}_{\mathrm{f}}$ \\
\hline \multirow{4}{*}{4.5} & 1 & 39.36 & 0.85 & 46.31 & \multirow{3}{*}{45.66} & \multirow{3}{*}{45.9} & \multirow{3}{*}{1.01} \\
\hline & 2 & 18.56 & 0.407 & 45.60 & & & \\
\hline & 3 & 38.15 & 0.846 & 45.08 & & & \\
\hline & 1 & 26.26 & 0.55 & 47.75 & \multirow{3}{*}{46.14} & \multirow{3}{*}{51.0} & \multirow{3}{*}{1.11} \\
\hline \multirow[t]{2}{*}{5.0} & 2 & 57.93 & 1.3 & 44.56 & & & \\
\hline & 3 & 53.96 & 1.17 & 46.12 & & & \\
\hline \multirow{3}{*}{5.5} & 1 & 40.52 & 0.870 & 46.57 & \multirow{3}{*}{46.50} & \multirow{3}{*}{56.11} & \multirow{3}{*}{1.21} \\
\hline & 2 & 18.36 & 0.385 & 47.68 & & & \\
\hline & 3 & 37.42 & 0.827 & 45.25 & & & \\
\hline
\end{tabular}


Table 4. Variation of cutting efficiency with pulley size

\begin{tabular}{ccccc}
\hline $\begin{array}{l}\text { Pulley size } \\
\text { (Inch) }\end{array}$ & $\begin{array}{c}\text { No of plant per } \mathrm{m}^{2} \\
\text { before reaping }(\mathrm{e})\end{array}$ & $\begin{array}{c}\text { No of uncut } \\
\text { plant } / \mathrm{m}^{2}(\mathrm{~d})\end{array}$ & $\begin{array}{c}\text { Cutting } \\
\text { efficiency }(\%)=\frac{e-d}{e} \times 100\end{array}$ & $\begin{array}{c}\text { Average } \\
\text { Cutting } \\
\text { efficiency }\end{array}$ \\
\hline \multirow{3}{*}{4.5} & 396 & 1 & 99.74 & \\
& 417 & 1 & 99.76 & \\
5.0 & 414 & 2 & 99.52 & \\
& 396 & 1 & 99.75 & \\
5.5 & 389 & 1 & 99.74 & \\
& 414 & 1 & 99.76 & \\
\hline
\end{tabular}
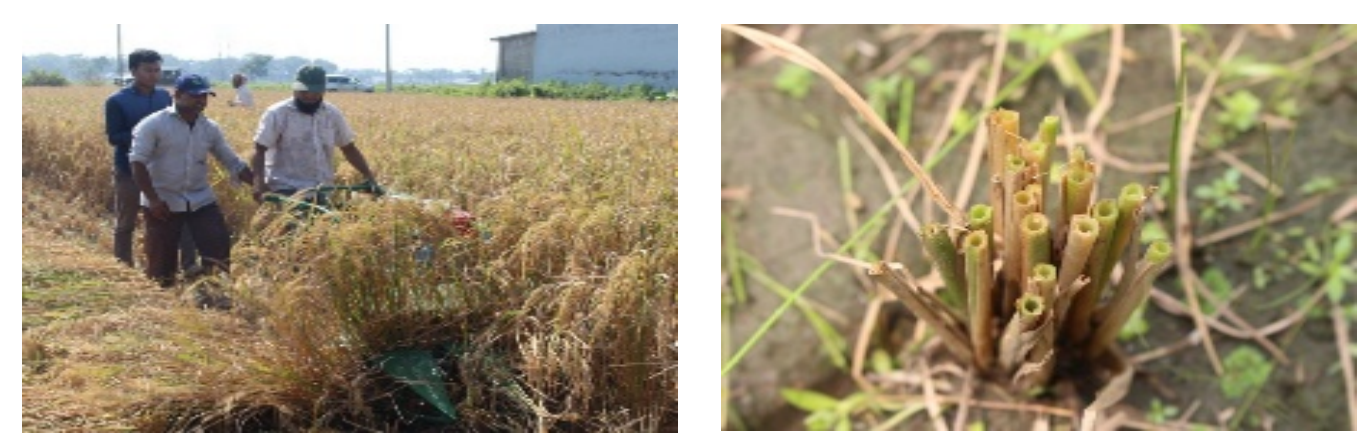

Fig. 6. Harvesting of paddy using 5.5" pulley

Harvesting cost saving by modified BAU selfpropelled reaper

Estimated manual and mechanical paddy harvesting costs are presented in Table 5. Manual paddy harvesting cost was $9200 \mathrm{Tk} / \mathrm{ha}$ which depends on the total number of required labors/ha and the labor wages rate. On the other hand, mechanical paddy harvesting cost using the modified BAU self-propelled reaper was $916 \mathrm{Tk} / \mathrm{ha}$ (including fixed cost \& variable cost). Compared to manual harvesting, mechanical harvesting saved 90\% cost as compared in Table 5.

Table 5. Harvesting cost saving using the modified BAU self-propelled reaper

\begin{tabular}{|c|c|c|c|c|c|c|}
\hline \multicolumn{3}{|c|}{ Manual harvesting cost } & \multicolumn{3}{|c|}{ Modified BAU self-propelled reaper } & \multirow[b]{2}{*}{$\begin{array}{c}\text { Cost saved over manual } \\
\text { method }(\%)\end{array}$} \\
\hline $\begin{array}{l}\text { Total no. of } \\
\text { labor/ ha }\end{array}$ & $\begin{array}{c}\text { Labor wage, } \\
\text { Tk/labor }\end{array}$ & $\begin{array}{c}\text { Total } \\
\text { cost } \\
(\mathrm{Tk} / \mathrm{ha})\end{array}$ & $\begin{array}{l}\text { Fixed cost } \\
(\mathrm{Tk} / \mathrm{ha})\end{array}$ & $\begin{array}{c}\text { Variable } \\
\text { cost } \\
(\mathrm{Tk} / \mathrm{ha})\end{array}$ & $\begin{array}{l}\text { Total cost } \\
(\mathrm{Tk} / \mathrm{ha})\end{array}$ & \\
\hline 23 & 400 & 9200 & 145 & 771 & 916 & 90 \\
\hline
\end{tabular}

\section{Benefit cost ratio (BCR)}

The benefit cost ratio (BCR) is an important factor to measure the profitability of the reaper. If the value of benefit cost ratio (BCR) is greater than unity, then it will be economically accepted. The benefit cost ratio (BCR) of the modified reaper was calculated from the gross return $(244800 \mathrm{Tk} / \mathrm{yr})$ dividing by the total harvesting cost (112118 Tk/yr). Based on the calculation, BCR of BAU self-propelled reaper was found 2.18 which indicates that using of BAU self-propelled reaper is profitable.

\section{Field losses for mechanical and manual harvesting systems}

The average harvesting losses, including shatter and cutter bar losses, of modified BAU self-propelled reaper and manual harvesting system are given in Table 6 .
Average shatter, cutter bar and total harvesting losses were found a) $0.22 \%, 0.24 \%$ and $0.46 \%$, respectively for BAU self-propelled reaper and b) $0.73 \%, 0.62 \%$ and $1.35 \%$, respectively for manual harvesting. All losses were more in manual harvesting system.

Table 6. Harvesting losses using modified BAU selfpropelled reaper and manual harvesting

\begin{tabular}{cccc}
\hline Method & $\begin{array}{r}\text { Shatter } \\
\text { loss, } \%\end{array}$ & $\begin{array}{c}\text { Cutter bar } \\
\text { loss, } \%\end{array}$ & $\begin{array}{c}\text { Total } \\
\text { loss, } \%\end{array}$ \\
\hline $\begin{array}{c}\text { Modified BAU self- } \\
\text { propelled reaper } \\
\text { Manual harvesting }\end{array}$ & 0.22 & 0.24 & 0.46 \\
\hline
\end{tabular}

\section{Conclusion}

Technical and economic performances of modified BAU self-propelled reaper were found better than that of existing BAU self-propelled reaper. Straw cutting 
performance of the reaper during harvesting operation was not affected using different cutting speeds. On the other hand, throwing performance increases gradually with increasing the ratio of cutting and forward speeds. Compared to manual harvesting, mechanical harvesting saved $90 \%$ cost. BAU self-propelled reaper also saved field losses of paddy in comparison to manual harvesting system. Based on the all calculations and analysis, BAU self-propelled reaper will be profitable for farmers.

\section{Acknowledgement}

This study as part of Appropriate Scale Mechanization Consortium (ASMC) project "Appropriate Scale Mechanization Innovation Hub (ASMIH) - Bangladesh", is made possible by the Feed the Future Innovation Lab for Sustainable Intensification through USAID and University of Illinois at Urbana-Champaign, USA.

\section{References}

BBS (Bangladesh Bureau of Statistics). 2016. Statistical Pocket Book of Bangladesh. Bangladesh Bureau of Statistics, Ministry of Planning, Government of the People's Republic of Bangladesh, Dhaka.

Barger, E.L., Kepner, R.A. and Roy, B. 1987. Principle of Farm Machinery- ${ }^{\text {rd }}$ Edition. New Delhi, India.

Hossain, M.D. 2003. Fabrication of self-propelled reaper by locally available materials. MS thesis, Department of Farm Power and Machinery, BAU, Mymensingh, Bangladesh.

Hunt, D. 1995. Farm power and machinery management, Cost determination, 9th edition, Iowa State University Press, USA.
Iqbal, M., Sheikh, G.S. and Sial, J.K. 1980. Harvesting and threshing losses of wheat with mechanical and conventional method. Agricultural Mechanization in Asia, Africa and Latin American (AMA). 10(3): 66-70.

Hossain, M.A. Hoque, M.A., Wohab, M.A., Miah, M.A.M. and Hassan, M.S. 2015. Technical and economic performance of combined harvester in farmers' field. Bangladesh J. Agril. Res. 40(2): 291-304.

Mandal, M.A.S. 2014. Agricultural mechanization in Bangladesh: role of policies and emerging private sector. Paper Presented at the NSD-IFPRI Workshop on Mechanization and Agricultural Transformation in Asia and Africa: Sharing Development Experiences. June 18-19, Beijing, China.

Mandal, M.A.S. 2002. Agricultural machinery manufacturing and farm mechanization: a case of rural non-farm economic development in Bangladesh. Paper Presented at International Workshop on Fostering Rural Economic Development through Agriculture-based Enterprises and Services. November 19-22, GTZ-Haus, Berlin, Germany.

Meisner, C.A., Petter, H., Badruddin, M., Razzaque, M.A., Giri, G.S. and Scott, J. 1997. Mechanical revolution among small landholders of South Asia: The growing use of Chinese hand tractors. Proc. of the Joint Intl. Conf. on Agril. Eng. \& Tech. Exhibition '97, Dhaka, 3: 781-787.

Pandey, M.M. and Devnani, R.S. 1985. Design, development and field evaluation of vertical conveyor reaper windrower. Agricultural Mechanization in Asia, Africa and Latin America (AMA). 16 (2): 41-52.

Samon, B and Duff, B. 1973. The pattern and magnitude of field grain losses in paddy production. IRRI Saturday Seminar Paper, July 7.

World Bank. 2016. Bangladesh: Growing the Economy through Advances in Agriculture. Project report, October 9.

Zhang, X., Rashid, S., Ahmad, K. and Ahmed, A. 2014. Escalation of real wages in Bangladesh: is it the beginning of structural transformation? World Dev. 64, 273-285. 